\title{
Effects of indole on drug resistance and virulence of Salmonella enterica serovar Typhimurium revealed by genome-wide analyses
}

Eiji Nikaido ${ }^{1,2,3 \dagger}{ }^{\text {E Etienne Giraud }}{ }^{4,5 \dagger}$, Sylvie Baucheron ${ }^{4,5}$, Suguru Yamasaki 1,2,3, Agnès Wiedemann ${ }^{4,5}$, Kousuke Okamoto ${ }^{3}$, Tatsuya Takagi ${ }^{3}$, Akihito Yamaguchi ${ }^{2,3}$, Axel Cloeckaert $^{4,5^{*}}$ and Kunihiko Nishino ${ }^{1 *}$

\begin{abstract}
Background: Many Gram-positive and Gram-negative bacteria produce large quantities of indole as an intercellular signal in microbial communities. Indole demonstrated to affect gene expression in Escherichia coli as an intra-species signaling molecule. In contrast to E. coli, Salmonella does not produce indole because it does not harbor tnaA, which encodes the enzyme responsible for tryptophan metabolism. Our previous study demonstrated that E. coli-conditioned medium and indole induce expression of the AcrAB multidrug efflux pump in Salmonella enterica serovar Typhimurium for inter-species communication; however, the global effect of indole on genes in Salmonella remains unknown.

Results: To understand the complete picture of genes regulated by indole, we performed DNA microarray analysis of genes in the S. enterica serovar Typhimurium strain ATCC 14028s affected by indole. Predicted Salmonella phenotypes affected by indole based on the microarray data were also examined in this study. Indole induced expression of genes related to efflux-mediated multidrug resistance, including ramA and acrAB, and repressed those related to host cell invasion encoded in the Salmonella pathogenicity island 1, and flagella production. Reduction of invasive activity and motility of Salmonella by indole was also observed phenotypically.
\end{abstract}

Conclusion: Our results suggest that indole is an important signaling molecule for inter-species communication to control drug resistance and virulence of $S$. enterica.

Keywords: AcrAB, Indole, RamA, Salmonella, SPI-1

\section{Background}

Bacteria communicate using small molecules by a process termed quorum sensing. Accumulation of quorum-sensing signals in growth medium indicates cell density. The use of chemical signals for bacterial communication is a widespread phenomenon [1-5]. In Gram-negative bacteria, these signals could be $N$-acyl derivatives of homoserine lactone, cyclic dipeptides, and quinolones [6-12]. These signals regulate various functions such as bioluminescence, differentiation, virulence, DNA transfer, and biofilm maturation [13-22].

\footnotetext{
* Correspondence: Axel.Cloeckaert@tours.inra.fr; nishino@sanken.osaka-u.ac.jp ${ }^{\dagger}$ Equal contributors

'Laboratory of Microbiology and Infectious Diseases, Institute of Scientific and Industrial Research, Osaka University, 8-1 Mihogaoka, Ibaraki, Osaka 567-00447, Japan

${ }^{4}$ INRA, UMR1282 Infectiologie et Santé Publique, F-37380 Nouzilly, France Full list of author information is available at the end of the article
}

The intestinal tract is colonized by approximately $10^{12}$ commensal bacteria including those belonging to the genus Escherichia [23-25]. Among Enterobacteriaceae, indole is produced by E. coli and certain Proteeae such as Proteus vulgaris, Providencia spp., and Morganella spp. [26]. Indole production is commonly used for Escherichia coli identification [26]. Indole is generated from tryptophan by the enzyme tryptophanase, encoded by tnaA [27]. Extracellular indole is found at high concentrations (over $600 \mu \mathrm{M}$ ) when $E$. coli is grown in enriched medium [28]. Furthermore, indole has also been found in human feces at comparable concentrations $(\sim 250-1100 \mu \mathrm{M})[29,30]$. Recent studies have also revealed that indole is an extracellular signal in E. coli, since it has been demonstrated to regulate uptake, synthesis, and degradation of amino acids in the stationary phase of planktonic cells [31], multicopy plasmid 
maintenance, cell division [32], biofilm formation [28], acid resistance [33], and expression of multidrug exporters in E. coli [34-36] as well as to regulate the pathogenicity island, including the locus of enterocyte effacement of pathogenic E. coli [37,38]. Indole has also been demonstrated as an important cell-signaling molecule for a population-based antibiotic resistance mechanism [39].

Salmonella enterica is a bacterial pathogen that causes various diseases in humans including gastroenteritis, bacteremia, and typhoid fever [40]. In contrast to E. coli, $S$. enterica does not harbor tnaA; therefore, this organism does not produce indole [41]. In our previous study, we demonstrated that an $E$. coli-conditioned medium and indole induced expression of the acrAB-tolC multidrug efflux system of Salmonella in a RamA regulatordependent manner [35]. This suggests that indole is used as a cell-signaling molecule in both intra- and interspecies communication. However, the global effect of indole on Salmonella remains to be elucidated.

We hypothesized that indole controls expression of a wide range of genes and plays a role in regulating the physiological functions of S. enterica serovar Typhimurium. Therefore, to reveal the complete picture of indolecontrolled genes, we conducted microarray analysis of genes affected by indole. Predicted Salmonella phenotypes affected by indole based on the microarray data were also examined in this study.

\section{Methods}

\section{Bacterial strains and growth conditions}

S. enterica serovar Typhimurium strains used in this study were the wild-type strain ATCC14028s [42] and its derivatives. These included strain NES114 which harbors a FLAG-tag fused at the chromosomal $\operatorname{ramA}$ gene (ramA-FLAG:: $\mathrm{Km}^{\mathrm{R}}$ ) and strain NES84 which carries a ramA reporter plasmid (ATCC 14028s/pNNramA) [35]. Derivatives also included various deletion mutants: $\mathrm{ramA}$ deletion mutant $14028 \mathrm{~s} \triangle \mathrm{ramA}:: \operatorname{kan}^{\mathrm{R}}$, ramR deletion mu-

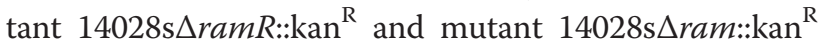
deleted of the whole ram locus. Bacterial strains were grown at $37^{\circ} \mathrm{C}$ in Luria-Bertani (LB) broth supplemented with indole (Sigma) where appropriate.

\section{DNA microarray analysis}

The ATCC 14028s strain was grown in the presence or absence of 1 or $4 \mathrm{mM}$ indole. The cells were rapidly collected for total RNA extraction when the culture reached an optical density (OD) of 0.6 at $600 \mathrm{~nm}$. Total RNA was extracted from the cells using the RNeasy Midi kit (Qiagen) and Turbo DNA-free ${ }^{\mathrm{ix}}$ kit (Ambion). After extraction of total RNA, fluorescent labeling of cDNA was performed using the GeneChip DNA labeling reagents (Affimetrix). The fluorescent-labeled cDNA was hybridized in cDNA microarray plates (NimbleExpress ${ }^{\mathrm{Tm}}$
S. typhimurium array; NimbleGen Systems, Inc.). The degree of fluorescence in the plates was measured and quantified using the GeneChip Scanner 3000 (Affymetrix) and GeneChip Operating Software ver. 1.4 (Affymetrix), respectively. Measured values were compared to control values, and $p$ values of distribution of logged data were obtained. A ranked conversion of $\mathrm{p}$ values was calculated, and values lying inside $2.5 \%$ of the two extremes were considered valid.

\section{Semiquantitative RT-PCR}

The ATCC 14028s strain was grown in the presence or absence of $2 \mathrm{mM}$ indole. The cells were rapidly collected for total RNA extraction when the culture reached an $\mathrm{OD}_{600}$ of 0.6. Total RNA from bacterial cultures was extracted as described above. Semiquantitative RT-PCR was used to measure the transcriptional expression of $r$ rs and $\operatorname{ramA}$. RNA was reverse-transcribed using random hexamers and TaqMan reverse transcription reagents (Applied Biosystems), and PCR was performed using Takara LA Taq DNA polymerase (Takara Bio, Inc.). The primers for $r r s$ were $r r s-\mathrm{F}$ and $r r s-\mathrm{R}$ (Table 1) and those for $\operatorname{ram} A$ were $\operatorname{ram} A-\mathrm{F}$ and $\operatorname{ram} A-\mathrm{R}$ (Table 1).

\section{$\beta$-Galactosidase assay}

The NES84 strain [35] was grown in the presence of 0-3 mM indole until an $\mathrm{OD}_{600}$ of 0.6 was reached. $\beta$-Galactosidase activity was determined as described by Miller [43]. All assays were performed in triplicate.

\section{Construction of the ramA-FLAG strain}

Insertion of the FLAG-tag of the $\operatorname{ramA}$ gene 3' terminal was performed as described by Datsenko and Wanner [44]. The kanamycin resistance gene $a p h$, flanked by Flp recognition sites, was amplified by PCR using the primers ramA-FLAG-forward (GCCAGGCGCTTATCGTA AAGAAAAGCAT GGCCG TACGCATGACTACAAGG ACGACGATGACAAGTAGGTGTAGGCTGGAGCTGC TTC) and ramA-FLAG-reverse (CGATTAAACATTTC AATGCGTACGGCCATGCTTTTCTTTACATATGAAT ATCCTCCTTAG). The sequence of the FLAG-tag appears in bold in the sequence of the ramA-FLAG- forward primer. The resulting PCR products were used to transform the recipient ATCC 14028s strain harboring the pKD46 plasmid, which expresses Red recombinase [44]. The chromosomal structure of the mutated loci was verified by PCR.

\section{Western blotting}

The NES114 strain (ramA-FLAG:: $\mathrm{Km}^{\mathrm{R}}$ ) was grown in the presence of $2 \mathrm{mM}$ indole until an $\mathrm{OD}_{600}$ of 0.6 was reached. Bacterial cells were washed with buffer $[20 \mathrm{mM}$ Tris- $\mathrm{HCl}$ (pH 8.0), $200 \mathrm{mM} \mathrm{NaCl}$, and $1 \mathrm{mM}$ EDTA], resuspended in $1 \mathrm{ml}$ of the same buffer, and disrupted by 
Table 1 Primers used in this study

\begin{tabular}{|c|c|}
\hline Primer name & Oligonucleotide sequence ( $5^{\prime}$ to $\left.3^{\prime}\right)$ \\
\hline \multicolumn{2}{|c|}{ For semiquantitative RT-PCR } \\
\hline$r r s-F$ & CCAGCAGCCGCGGTAAT \\
\hline$r r s-R$ & TTAACGCCCAGTAATTCCGATT \\
\hline $\operatorname{ramA-F}$ & ATTTGAATCAGCCGTTACGTATTG \\
\hline $\operatorname{ramA-R}$ & TGCAGGTGCCACTTGGAAT \\
\hline \multicolumn{2}{|c|}{ For quantitative RT-PCR } \\
\hline$g m k-f$ & TTGGCAGGGAGGCGTTT \\
\hline$g m k-r$ & GCGCGAAGTGCCGTAGTAAT \\
\hline gyrB-f & TCTCCTCACAGACCAAAGATAAGCT \\
\hline gyrB-r & CGCTCAGCAGTTCGTTCATC \\
\hline$r r s-f$ & CCAGCAGCCGCGGTAAT \\
\hline$r r s-r$ & TTAACGCCCAGTAATTCCGATT \\
\hline $\operatorname{ramA-f}$ & GCGTGAACGGAAGCTAAAAC \\
\hline $\operatorname{ramA-r}$ & GGCCATGCTITTCTITACGA \\
\hline$\overline{a c r B-f}$ & TCGTGTTCCTGGTGATGTACCT \\
\hline$a c r B-r$ & AACCGCAATAGTCGGAATCAA \\
\hline$m d t E-f$ & AGTCGCTGGATACCACCATC \\
\hline$m d t E-r$ & GATATTACGCACGCCGATTT \\
\hline to/C-f & GCCCGTGCGCAATATGAT \\
\hline to/C-r & CCGCGTTATCCAGGTTGTTG \\
\hline$f l h C-f$ & ATATCCAGTTGGCGATGGAG \\
\hline$f l h C-r$ & TTGCTCCCAGGTCATAAACC \\
\hline hilA-f & CATGGCTGGTCAGTTGGAG \\
\hline hilA-r & CGTAATTCATCGCCTAAACG \\
\hline invF-f & TGAAAGCCGACACAATGAAAAT \\
\hline invF-r & GCCTGCTCGCAAAAAAGC \\
\hline invA-f & GGCGCCAAGAGAAAAAGATG \\
\hline inva-r & CAAATATAACGCGCCATTGCT \\
\hline$\overline{s i p A-f}$ & TTGGGTGTACGTTAGATCCGTTA \\
\hline $\operatorname{sip} A-r$ & CCGCCGCTITGTCAACA \\
\hline
\end{tabular}

sonication using the Branson Sonifier 200 (Branson Sonic Power Co., Danbury, CT, USA) on ice for $2.5 \mathrm{~min}$. Whole-cell lysate (10 $\mu \mathrm{g}$ of protein) was separated on $15 \%$ SDS-PAGE using Tris-glycine SDS as the running buffer. The gel was transferred to PVDF membranes, and analyzed by western blotting using a monoclonal anti-FLAG antibody (Sigma). The blot was developed using anti-mouse IgG horseradish peroxidase-conjugated antibody and analyzed using the ECL detection system (GE Healthcare).

\section{Transmission electron microscopy}

One hundred microliters of an overnight culture of the wild-type Salmonella strain was added to $5 \mathrm{ml}$ of LB broth, and the bacterial culture was grown in the presence or absence of $1 \mathrm{mM}$ indole until an $\mathrm{OD}_{600}$ of 0.6 was reached. Bacterial cells were collected by centrifugation, fixed in $2 \%$ glutaraldehyde solution, and observed using a transmission electron microscope JEM-2100 (JEOL Ltd.).

\section{Gene expression analysis by qRT-PCR}

Bacteria were grown until mid-log phase $\left(\mathrm{OD}_{600}\right.$ of 0.6$)$ and harvested by centrifugation. Pelleted cultures were stabilized with RNAprotect Bacteria Reagent (Qiagen) and stored at $-80{ }^{\circ} \mathrm{C}$ until use. Total RNA was extracted using the RNeasy Mini kit. (Qiagen) following the manufacturer's instructions. Removal of residual genomic DNA was performed using the Turbo DNA-free kit (Ambion) and examined by negative PCR amplification of a chromosomal sequence. RNA integrity was examined by electrophoresis on $1 \%$ agarose gel. Total RNA was reverse-transcribed using random hexamers and the Superscript III First Strand Synthesis System (Applied Biosystems). Primers used for qRT-PCR are listed in Table 1. The cycling conditions were as follows: $95{ }^{\circ} \mathrm{C}$ for $5 \mathrm{~min}$ followed by 40 cycles of $95{ }^{\circ} \mathrm{C}$ for $10 \mathrm{~s}$ and $60{ }^{\circ} \mathrm{C}$ for $15 \mathrm{~s}$. After each run, amplification specificity and the absence of primer dimers were examined using a dissociation curve acquired by heating the PCR products from 60 to $95{ }^{\circ} \mathrm{C}$. The relative quantities of transcripts were determined using the standard curve method and normalized against the geometric mean of three reference genes $(\mathrm{gmk}$, gyr $B, r r s)$. In qRT-PCR experiments performed to address the effect of $1 \mathrm{mM}$ indole, the expression level of each gene of interest was calculated as the average of three independent RNA samples. A two-tailed Student's $t$-test was used to assess significance using a $p$ value of $<0.05$ as a cutoff.

\section{Measurement of motility of Salmonella}

An overnight culture of the ATCC 14028s Salmonella strain was diluted in LB broth and grown in the presence or absence of $1 \mathrm{mM}$ indole until an $\mathrm{OD}_{600}$ of 0.6 was reached. Next, $1 \mu \mathrm{l}$ of bacterial culture was spotted in the center of a semi-solid agar plate containing $1 \%$ tryptone peptone and $0.3 \%$ BactoAgar and incubated at $37{ }^{\circ} \mathrm{C}$ for $3-5 \mathrm{~h}$ in a humidified incubator, after which strains were assessed for motility.

\section{Invasion assay}

Invasions assays were essentially performed as previously described [45]. Caco-2 cells were grown in Dulbecco's modified Eagle medium (DMEM) supplemented with $10 \%$ inactivated fetal bovine serum, $1 \%$ nonessential amino acids, and $1 \%$ antibiotic solution (Gibco, Invitrogen). Cells harvested by trypsinization were seeded at $2 \times 10^{5}$ cells/well in a 24-well plate (Falcon) and incubated for 4 days at $37{ }^{\circ} \mathrm{C}$ under $5 \% \mathrm{CO}_{2}$ in the medium described above, to obtain a confluent monolayer. Antibiotic was removed $24 \mathrm{~h}$ before performing the invasion assays. Bacteria were grown to an $\mathrm{OD}_{600}$ of 0.6 in $\mathrm{LB}$ 
broth in the presence or absence of $1 \mathrm{mM}$ indole. After washing with DMEM, bacteria were inoculated on Caco-2 cells at a multiplicity of infection of 30 , and the plates were further incubated for $30 \mathrm{~min}$. The bacteria-containing medium was removed from the wells, and the cells were washed with PBS. Cells were incubated for $1.5 \mathrm{~h}$ with DMEM supplemented with $100 \mu \mathrm{g} / \mathrm{ml}$ gentamicin. Cells were washed with PBS and lysed by the addition of sterile ultrapure water for $30 \mathrm{~min}$. Serial dilutions were plated on LB agar. The percentage of penetrating bacteria was calculated on the basis of the ratio of the counted cfu to the bacterial inoculum. For each bacterial strain and for each condition, three replicates were used.

\section{Results}

\section{Indole affects gene expression in Salmonella}

The regulation of Salmonella genes in the wild-type strain ATCC 14028 s by 1 or $4 \mathrm{mM}$ indole, was analyzed using DNA microarray. To exclude noise data based on microarray analysis, we considered that genes for which expression changed in the presence of both 1 and $4 \mathrm{mM}$ of indole were significantly regulated by indole. As a result, it was revealed that 24 (Table 2) and 53 genes (Table 3) were upregulated and downregulated by indole, respectively.

\section{Genes upregulated by indole}

Expression of the 24 genes listed in Table 2 was upregulated by both 1 and $4 \mathrm{mM}$ indole. Eighteen genes are considered to code for putative proteins, and four genes, $\operatorname{ram} A, y d i P, y h j B$, and $b g l J$, are regulatory in nature. The transcriptional activator RamA, which belongs to the AraC/XylS family of regulatory proteins, promotes multidrug resistance by increasing expression of the AcrABTolC multidrug efflux system in several pathogenic Enterobacteriaceae [35,46-53]. RamA has also been reported to negatively affect virulence [47]. Both YdiP and $\mathrm{YhjB}$ are putative transcription regulators that belong to the AraC and LuxR/UhpA families, respectively (Table 2). YhjB is considered a response regulator

Table 2 Salmonella genes whose relative expression was increased by indole

\begin{tabular}{|c|c|c|c|c|}
\hline \multirow[t]{3}{*}{ STM no. } & \multirow[t]{3}{*}{ Gene } & \multirow[t]{3}{*}{ Function } & \multicolumn{2}{|c|}{$\begin{array}{l}\text { Effect of indole on gene } \\
\text { expression (fold change) }\end{array}$} \\
\hline & & & \multicolumn{2}{|c|}{ Concentration of indole (mM) } \\
\hline & & & 1 & 4 \\
\hline STM0521 & $y b b V$ & Putative cytoplasmic protein & 8.6 & 7.0 \\
\hline STM0581 & $\operatorname{ramA}$ & Transcriptional regulator (activator) of $a c r A B$ and tolC (AraC/XylS family) & 7.0 & 39 \\
\hline STM0584 & entD & Enterochelin synthetase, component D (phoshpantetheinyltransferase) & 6.1 & 7.5 \\
\hline STM0707 & $k d p F$ & Putative outer membrane protein & 8.6 & 18 \\
\hline STM0823 & ybil & Putative periplasmic protein & 3.2 & 11 \\
\hline STM1156 & yceA & Putative enzyme related to sulfurtransferases & 4.3 & 8.0 \\
\hline STM1214 & $y c f R$ & Putative outer membrane protein & 4.6 & 37 \\
\hline STM1251 & & Putative molecular chaperone (small heat shock protein) & 11 & 9.2 \\
\hline STM1355 & ydip & Putative transcription regulator, AraC family & 11 & 7.5 \\
\hline STM1472 & & Putative periplasmic protein & 7.5 & 15 \\
\hline STM1790 & hyaE & Putative thiol-disulfide isomerase and thioredoxins & 7.0 & 9.2 \\
\hline STM1868A & & Putative protein & 4.3 & 7.0 \\
\hline STM2103 & wcal & $\begin{array}{l}\text { Putative UDP-glucose lipid carrier transferase/glucose-1-phosphate transferase in } \\
\text { colanic acid gene cluster }\end{array}$ & 4.0 & 5.3 \\
\hline STM2106 & wcal & Putative glycosyl transferase in colanic acid biosynthesis & 4.6 & 34 \\
\hline STM2206 & fruF & Phosphoenolpyruvate-dependent sugar phosphotransferase system, EllA 2 & 4.6 & 12 \\
\hline STM3028 & $s t d B$ & Putative outer membrane usher protein & 6.5 & 6.5 \\
\hline STM3444 & $b f d$ & Regulatory or redox component complexing with Bfr, in iron storage and mobility & 8.0 & 20 \\
\hline STM3511 & yhgl & Putative thioredoxin-like proteins and domain & 5.7 & 8.0 \\
\hline STM3606 & $y$ yji & Putative transcriptional regulator (LuxR/UhpA familiy) & 7.0 & 20 \\
\hline STM3668 & yiak & Putative malate dehydrogenase & 7.0 & 9.2 \\
\hline STM3941 & & Putative inner membrane protein & 8.6 & 18 \\
\hline STM4213 & & Putative phage tail sheath protein & 6.5 & 5.7 \\
\hline STM4327 & fXsA & Suppresses $\mathrm{F}$ exclusion of bacteriophage $\mathrm{T7}$ & 4.9 & 5.7 \\
\hline STM4548 & bglJ & Transcriptional regulator (activator) of bg/ operon (LuxR/UhpA family) & 26 & 5.7 \\
\hline
\end{tabular}


Table 3 Salmonella genes whose relative expression was decreased by indole

\begin{tabular}{|c|c|c|c|c|}
\hline \multirow[t]{3}{*}{ STM no. } & \multirow[t]{3}{*}{ Gene } & \multirow[t]{3}{*}{ Function } & \multicolumn{2}{|c|}{$\begin{array}{l}\text { Effect of indole on gene } \\
\text { expression (fold change) }\end{array}$} \\
\hline & & & \multicolumn{2}{|c|}{ Concentration of indole (mM) } \\
\hline & & & 1 & 4 \\
\hline STM0701 & speF & Ornithine decarboxylase isozyme, inducible & 0.35 & 0.038 \\
\hline STM0964 & $d m s A$ & Anaerobic dimethyl sulfoxide reductase, subunit A & 0.12 & 0.063 \\
\hline STM0965 & $d m s B$ & Anaerobic dimethyl sulfoxide reductase, subunit B & 0.13 & 0.025 \\
\hline STM1092 & orf & Putative cytoplasmic protein & 0.082 & 0.031 \\
\hline STM1171 & $f l g N$ & Flagellar biosynthesis: belived to be export chaperone for FlgK and FlgL & 0.27 & 0.082 \\
\hline STM1183 & $f l g k$ & Flagellar biosynthesis, hook-filament junction protein 1 & 0.19 & 0.031 \\
\hline STM1184 & flgL & Flagellar biosynthesis; hook-filament junction protein & 0.18 & 0.044 \\
\hline STM1626 & $\operatorname{trg}$ & Methyl-accepting chemotaxis protein III, ribose and galactose sensor receptor & 0.15 & 0.054 \\
\hline STM1732 & ompW & Outer membrane protein W; colicin S4 receptor; putative transporter & 0.29 & 0.047 \\
\hline STM1764 & narG & Nitrate reductase 1, alpha subunit & 0.095 & 0.041 \\
\hline STM1765 & nark & MFS superfamily, nitrite extrusion protein & 0.058 & 0.047 \\
\hline STM1917 & cheB & Methyl esterase, response regulator for chemotaxis (cheA sensor) & 0.27 & 0.067 \\
\hline STM1918 & cher & Glutamate methyltransferase, response regulator for chemotaxis & 0.14 & 0.0078 \\
\hline STM1919 & cheM & Methyl accepting chemotaxis protein II, aspartate sensor-receptor & 0.18 & 0.018 \\
\hline STM1921 & cheA & $\begin{array}{l}\text { Sensory histitine protein kinase, transduces signal between chemo- signal receptors } \\
\text { and CheB and CheY }\end{array}$ & 0.18 & 0.029 \\
\hline STM1922 & motB & Enables flagellar motor rotation, linking torque machinery to cell wall & 0.15 & 0.021 \\
\hline STM1923 & motA & Proton conductor component of motor, torque generator & 0.20 & 0.036 \\
\hline STM1960 & fliD & Flagellar biosynthesis; filament capping protein; enables filament assembly & 0.31 & 0.011 \\
\hline STM1961 & flis & Flagellar biosynthesis; repressor of class 3a and 3b operons (RflA activity) & 0.31 & 0.019 \\
\hline STM1962 & fliT & Flagellar biosynthesis; possible export chaperone for FliD & 0.25 & 0.038 \\
\hline STM2256 & napB & Periplasmic nitrate reductase, small subunit, cytochrome C550, in complex with NapA & 0.23 & 0.082 \\
\hline STM2257 & napH & Ferredoxin-type protein: electron transfer & 0.12 & 0.067 \\
\hline STM2258 & napG & Ferredoxin-type protein: electron transfer & 0.077 & 0.027 \\
\hline STM2259 & napA & Periplasmic nitrate reductase, large subunit, in complex with NapB & 0.072 & 0.033 \\
\hline STM2260 & napD & Periplasmic nitrate reductase & 0.063 & 0.0078 \\
\hline STM2261 & napF & Ferredoxin-type protein: electron transfer & 0.044 & 0.024 \\
\hline STM2872 & prg」 & Cell invasion protein; cytoplasmic & 0.22 & 0.10 \\
\hline STM2873 & prgl & Cell invasion protein; cytoplasmic & 0.18 & 0.041 \\
\hline STM2874 & $\mathrm{prgH}$ & Cell invasion protein & 0.082 & 0.0078 \\
\hline STM2885 & $\operatorname{sip} B$ & Cell invasion protein & 0.33 & 0.11 \\
\hline STM2897 & $\operatorname{inv} E$ & Invasion protein & 0.25 & 0.038 \\
\hline STM2899 & invF & Invasion protein & 0.12 & 0.095 \\
\hline STM3127 & & Putative cytoplasmic protein & 0.29 & 0.058 \\
\hline STM3128 & & Putative oxidoreductase & 0.14 & 0.036 \\
\hline STM3129 & & Putative NAD-dependent aldehyde dehydrogenase & 0.14 & 0.047 \\
\hline STM3149 & hybA & $\begin{array}{l}\text { Function unknown, intitally thought to be hydrogenase-2 small subunit which now } \\
\text { identified as hybO }\end{array}$ & 0.25 & 0.025 \\
\hline STM3216 & & Putative methyl-accepting chemotaxis protein & 0.16 & 0.038 \\
\hline STM3217 & aer & Aerotaxis sensor receptor, senses cellular redox state or proton motive force & 0.13 & 0.047 \\
\hline STM3242 & $t d c D$ & Propionate kinase/acetate kinase II, anaerobic & 0.14 & 0.029 \\
\hline STM3243 & $\operatorname{tdcC}$ & HAAAP family, L-threonine/L-serine permease, anaerobically inducible & 0.082 & 0.044 \\
\hline STM3244 & $t d c B$ & Threonine dehydratase, catabolic & 0.063 & 0.029 \\
\hline STM3245 & $t d c A$ & Transcriptional activator of tdc operon (LysR family) & 0.18 & 0.095 \\
\hline STM3577 & $t c p$ & Methyl-accepting transmembrane citrate/phenol chemoreceptor & 0.13 & 0.041 \\
\hline
\end{tabular}


Table 3 Salmonella genes whose relative expression was decreased by indole (Continued)

\begin{tabular}{|c|c|c|c|c|}
\hline STM3626 & $d p p F$ & ABC superfamily (atp_bind), dipeptide transport protein & 0.31 & 0.036 \\
\hline STM3628 & $d p p C$ & ABC superfamily (membrane), dipeptide transport protein 2 & 0.33 & 0.088 \\
\hline STM4258 & & Putative methyl-accepting chemotaxis protein & 0.08 & 0.088 \\
\hline STM4300 & fumB & Fumarase B (fumarate hydratase class I), anaerobic isozyme & 0.19 & 0.088 \\
\hline STM4305 & & Putative anaerobic dimethyl sulfoxide reductase, subunit A & 0.14 & 0.082 \\
\hline STM4306 & & Putative anaerobic dimethyl sulfoxide reductase, subunit B & 0.11 & 0.058 \\
\hline STM4452 & $n r d D$ & Anaerobic ribonucleoside-triphosphate reductase & 0.047 & 0.095 \\
\hline STM4465 & & Putative ornithine carbamoyltransferase & 0.19 & 0.10 \\
\hline STM4466 & & Putative carbamate kinase & 0.19 & 0.10 \\
\hline STM4467 & & Putative arginine deiminase & 0.082 & 0.019 \\
\hline
\end{tabular}

comprising a CheY-like receiver domain and a helixturn-helix DNA-binding domain. YhjB in E. coli stimulates dephosphorylation of two histidine kinases, EnvZ and NtrB, although the sensor kinase for YhjB phosphorylation has not yet been identified [54]. BglJ forms a heterodimer with RcsB to relieve repression of the $E$. coli bgl operon and allow arbutin and salicin transport and utilization [55,56]. Expression of all these regulatory genes increased by more than 10-fold in the presence of indole. Of particular interest, expression of $\operatorname{ram} A$ increased by 39 -fold in response to $4 \mathrm{mM}$ indole. Noticeably, higher indole concentration did not always lead to a higher expression level. Indeed, bglJ expression was more increased in response to $1 \mathrm{mM}$ indole (26-fold) than to $4 \mathrm{mM}$ indole (5.7-fold).

Among other genes upregulated by indole, functions of the gene products of $e n t D, f r u F, b f d$, and $f x s A$ have been characterized. EntD has phosphopantetheinyl transferase activity [57] and is involved in biosynthesis of the ironacquiring siderophore enterobactin [58]. FruF is a bifunctional PTS system fructose-specific transporter subunit IIA/HPr protein $[41,59]$. Bfd is a bacterioferritinassociated ferredoxin considered to be involved in Bfr iron storage and release functions or in regulation of $\mathrm{Bfr}$ [41]. FxsA of E. coli was described as a suppressor of the $\mathrm{F}$ exclusion of phage T7 [60]. Expression of all these genes was more strongly induced by $4 \mathrm{mM}$ indole than by $1 \mathrm{mM}$ indole.

\section{Genes downregulated by indole}

Microarray analysis revealed that fifty-three genes were repressed by both 1 and $4 \mathrm{mM}$ indole (Table 3 ). Expression of all these genes excluding STM4258 and $n r d D$ was reduced by $4 \mathrm{mM}$ indole compared to that by $1 \mathrm{mM}$ indole. Although there are 10 putative genes, functions of most gene products have been characterized (Table 3).

Microarray analysis revealed that indole represses expression of genes related to bacterial motility including flagella biosynthesis $(f l g N / K / L$ and $f l i D / S / T)$, chemotaxis (cheB/R/M/A, aer [61], tcp, and $t r g)$, and flagella motor activity $(m o t B / A)$. Indole also decreased expression of genes related to cell invasion such as $\mathrm{prgJ} / \mathrm{I} / \mathrm{H}, \operatorname{sip} B$, and $i n v E / F$, which are encoded by the Salmonella pathogenicity island 1 (SPI-1). Expression of genes related to anaerobic respiration was decreased by indole. The genes repressed by indole included narG (nitrate reductase), narK (nitrate-nitrite antiporter), and genes in the nap operon encoding nitrate reductase (Nap) such as napB/ $H / G / A / D / F$ [62]. The $t d c$ operon including $t d c A / B / C / D$, which are responsible for the anaerobic degradation of threonine [63], was also downregulated by indole. In addition to these genes, other genes related to anaerobic respiration such as $d m s A / B$ (anaerobic dimethyl sulfoxide reductase), fum $B$ (fumarase $B$, anaerobic isozyme), $n r d D$ (anaerobic ribonucleoside-triphosphate reductase), and STM4305/4306 (putative anaerobic dimethyl sulfoxide reductase, subunit $\mathrm{A} / \mathrm{B}$ ) were also repressed by indole. Indole also repressed membrane protein genes such as ompW (outer membrane protein involved in osmoregulation that is also affected by environmental conditions) and $d p p F / C$ (dipeptide transport protein).

\section{Indole upregulates genes involved in efflux-mediated multidrug resistance}

As reported above, microarray analysis identified that indole significantly increased expression of $\operatorname{ram} A$, encoding a transcriptional activator of the multidrug transporter genes $a c r A B$ and tolC of Salmonella [35]. To confirm this result, we performed reverse transcriptase polymerase chain reaction (RT-PCR) and observed that transcript levels of $\operatorname{ram} A$ increased when bacterial cells of the strain ATCC 14028s were treated with $2 \mathrm{mM}$ indole (Figure 1A-1). To investigate whether indole induces production of RamA, we constructed a strain NES114 that harbors a FLAG-tag fused to chromosomallyencoded $\operatorname{ramA}$. Western blotting revealed increased production of RamA in the presence of $2 \mathrm{mM}$ indole (Figure 1A-2). Microarray analysis demonstrated that expression of $\operatorname{ram} A$ was more strongly induced by $4 \mathrm{mM}$ indole (39fold increase relative to untreated cells) than by $1 \mathrm{mM}$ 

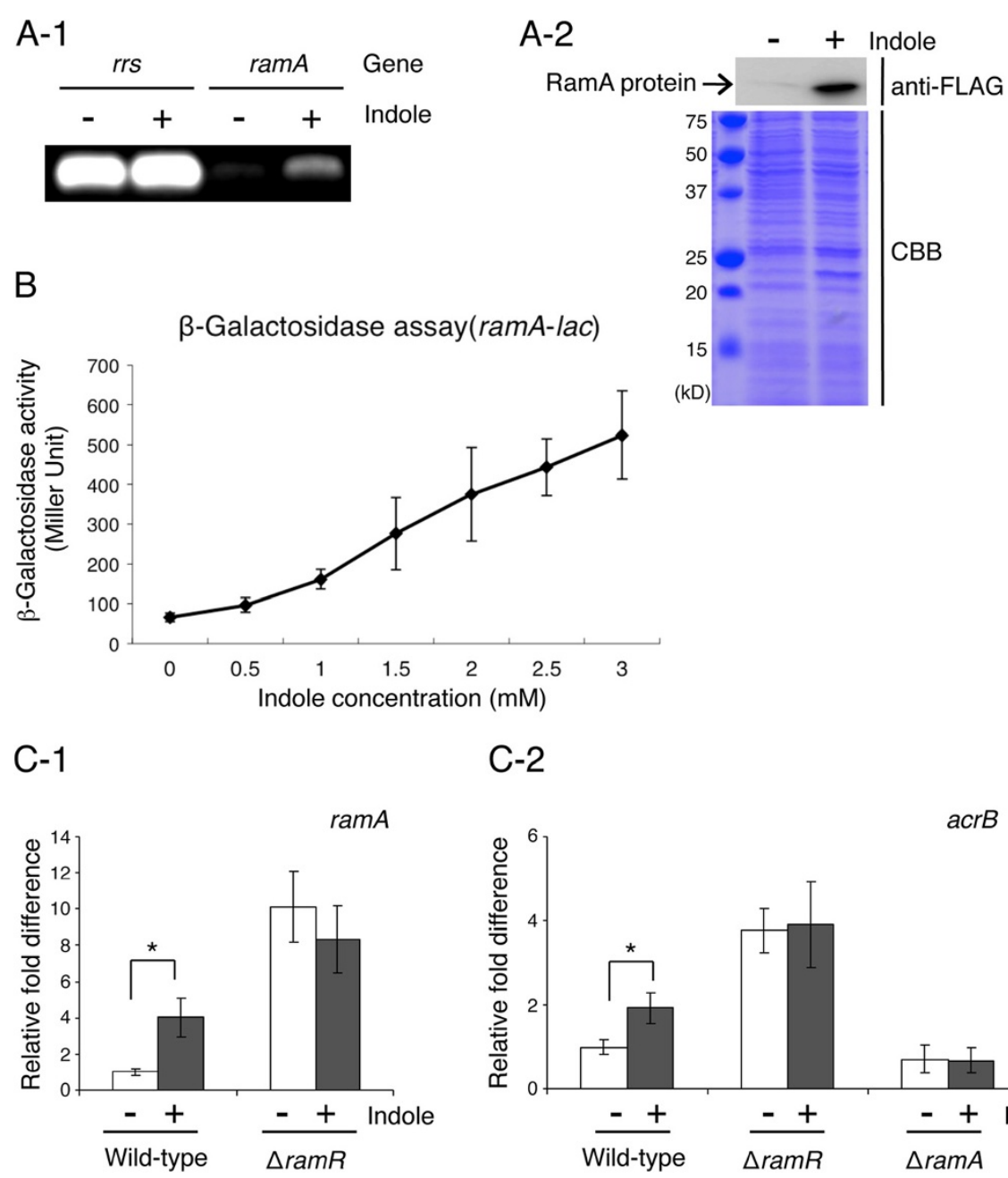

C-2

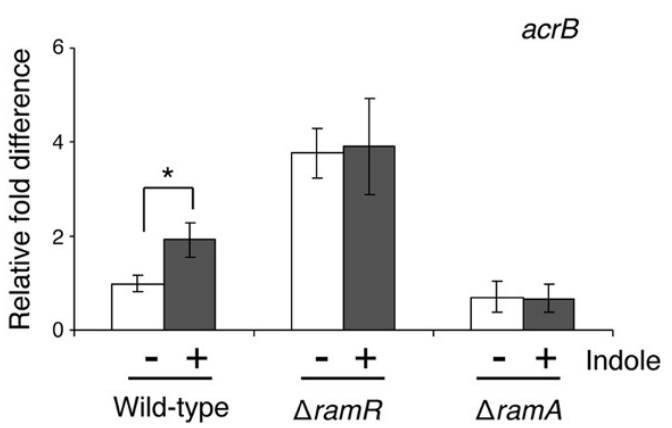

Figure 1 Indole induces efflux-mediated multidrug resistance genes. (A-1) RT-PCR measurement of indole effect on expression of ramA. Expression of rrs, encoding rRNA, was measured as a control. The wild-type strain ATCC14028s was grown in the presence (+) or absence (-) of $2 \mathrm{mM}$ indole, and RT-PCR was performed after RNA isolation. (A-2) RamA production in the wild-type ATCC14028s derivative strain carrying the epitope-tagged ramA. NES114 (ramA-FLAG::Km ${ }^{\mathrm{R}}$ ) was grown in the presence (+) or absence (-) of 2 mM indole. SDS-PAGE of lysates of NES114 was followed by Western blotting with an anti-FLAG antibody (anti-FLAG, top) or by staining with Coomassie brilliant blue (CBB, bottom). (B) $\beta$-Galactosidase levels in the wild-type ATCC 14028s derivative strain carrying the ramA-lac transcriptional fusion (NES84) treated with different indole concentrations. (C-1) qRT-PCR measurement of indole effect on expression of ramA. The wild-type strain (ATCC14028s) and its ramR:: $\mathrm{kan}^{R}$ deletion mutant were grown in the presence (+) or absence (-) of $1 \mathrm{mM}$ indole. (C-2) qRT-PCR measurement of indole effect on expression of acrB. The wild-type strain ATCC14028s and its ramR::kan ${ }^{R}$ and ramA::kan ${ }^{R}$ deletion mutants were grown in the presence (+) or absence $(-)$ of $1 \mathrm{mM}$ indole. (B and $\mathbf{C - 1}, \mathbf{2})$ The data correspond to mean values from three independent replicates. The bars indicate the standard deviation. (C-1, 2) $\operatorname{ram} A$ and $a c r B$ expression levels were expressed relative to that measured in the wild-type strain grown without indole, which was assigned the unit value. Asterisks indicate statistically significant difference $(p<0.05)$ according to a two-tailed Student's $t$-test.

indole (7.0-fold increase), indicating that the effect of indole on expression of $\operatorname{ram} A$ may be concentration dependent. To investigate the effect of different indole concentrations on the promoter activity of $\operatorname{ramA}$, a $\beta$-galactosidase assay with the NES84 strain [35] was performed, and it was found that indole activated the ramA promoter in a concentration-dependent manner (Figure 1B). The finding of enhanced promoter activity of ramA is in good agreement with our previous observation [35].
Confirming classical RT-PCR results, quantitative RT-PCR (qRT-PCR) indicated that expression of $\operatorname{ramA}$ in the strain ATCC 14028s increases by 4-fold in the presence of $1 \mathrm{mM}$ indole (Figure 1C-1). As previously reported, RamR represses to the same extent the expression of $\operatorname{ramA}[46,64]$. Therefore, to determine a possible contribution of RamR to induction of expression of $\operatorname{ram} A$ via indole, the effect of $1 \mathrm{mM}$ indole on expression of $\operatorname{ram} A$ in a $\Delta r a m R$ strain $\left(14028 \mathrm{~s} \Delta \operatorname{ramR}:: \operatorname{kan}^{\mathrm{R}}\right)$ was examined. At this concentration indole did not induce 
expression of $\operatorname{ram} A$ suggesting indole-mediated $\operatorname{ram} A$ induction is indeed dependent on the presence of RamR (Figure 1C-1). However, whereas indole was shown to induce expression of $a c r B$ in the wild-type strain, this induction was neither observed in the $\triangle \operatorname{ramR}\left(14028 \mathrm{~s} \Delta \mathrm{ramR}:: \mathrm{kan}^{\mathrm{R}}\right)$ nor in the $\Delta \operatorname{ram} A$ strain $\left(14028 \mathrm{~s} \Delta \mathrm{ram} A:: \mathrm{kan}^{\mathrm{R}}\right.$ ) (Figure 1C-2). This suggested that indole-mediated induction of $a c r B$ expression is not solely dependent on RamA, but nevertheless also requires the presence of the RamR transcriptional repressor.

\section{Indole represses motility of Salmonella}

Expression of genes related to bacterial flagella biosynthesis, flagella motor activity, and chemotaxis was repressed by indole, and this repression was predicted to have profound negative effects on flagellar synthesis and bacterial motility. FlhC is a master regulator protein involved in flagellar biogenesis in Salmonella [65]. Indole also reduced expression of $f l h C$, and this reduction was independent of $\operatorname{ramA}$ and $\mathrm{ramR}$ (Figure 2A). To confirm the microarray findings, we examined the effect of indole on the presence of flagella in wild-type Salmonella cells by transmission electron microscopy (Figure 2B). Flagella were detectable in bacterial cells regardless of indole treatment; however, the number of flagella decreased when cells were treated with indole (Figure 2B and C). It was observed that motility of Salmonella ATCC 14028s strain decreased in the semi-solid agar plate when bacterial cells were treated with indole (Figure 2D). These results suggest that the reduction in the number of flagella by indole may affect motility of Salmonella.

\section{Indole represses expression of the invasion genes}

Inside the host, $S$. enterica serovars can invade and survive in epithelial cells and macrophages. Therefore, invasion of the host intestinal cells is critical for initiation of salmonellosis. Several genetic elements responsible for the invasive phenotype of S. enterica serovar Typhimurium are located in SPI-1, a 40-kbp region of the chromosome at centrisome 63. As described above, we found that genes located in SPI-1 such as $\mathrm{prgJ} / \mathrm{I} / \mathrm{H}$, $\operatorname{sipB}$, and $i n v E / F$ were repressed by indole. To further investigate repression of SPI-1 genes by indole, we measured expression of hilA, $\operatorname{sip} A, \operatorname{inv} A$, and $i n v F$ of the ATCC 14028 s strain in response to different indole concentration by qRT-PCR (Figure 3). hilA is located on SPI-1, and it encodes the HilA regulator, which controls
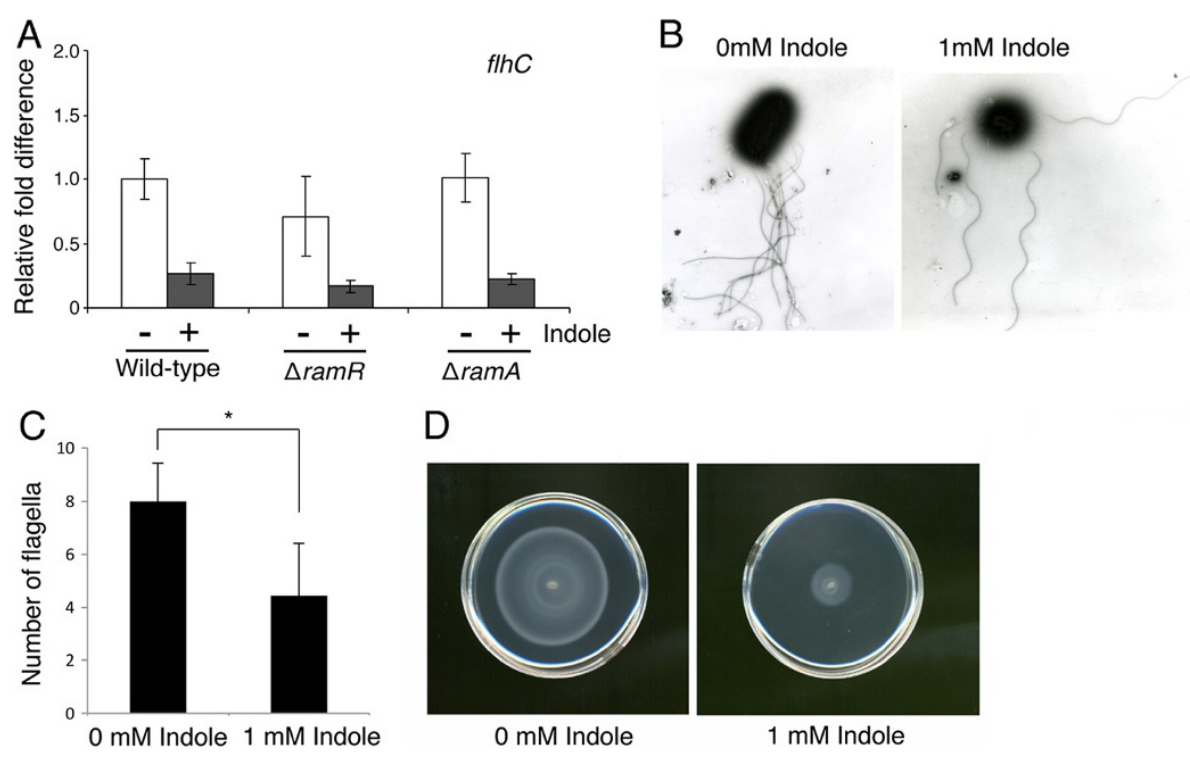

Figure $\mathbf{2}$ Indole represses flagella production and motility of Salmonella. (A) The effect of indole on expression of flhC measured by qRT-PCR. The wild-type strain ATCC 14028s and its ramR::kan ${ }^{R}$ and ramA::kan ${ }^{R}$ deletion mutants were grown in the presence $(+)$ or absence $(-)$ of $1 \mathrm{mM}$ indole. flhC expression level was expressed relative to that measured in the wild-type strain grown without indole, which was assigned the unit value. The data corresponds to mean values from three independent replicates. The bars indicate the standard deviation. (B) Transmission electron microscopy was used to detect flagella on the wild-type strain (ATCC 14028s) grown in the presence or absence of $1 \mathrm{mM}$ indole. (C) The number of flagella attached to a single cell was counted from images taken using transmission electron microscopy. Data were collected from 30 bacterial cells for both indole-treated and untreated cells. Bars correspond to the standard deviation. Asterisks indicate statistically significant differences $(p<0.01)$ according to the two-tailed Student's $t$-test. (D) Indole represses motility of Salmonella. After incubation of the wild-type ATCC 14028s strain in the presence or absence of $1 \mathrm{mM}$ indole, motility was assayed on a semi-solid agar plate. Result is representative of one of the three experiments. 


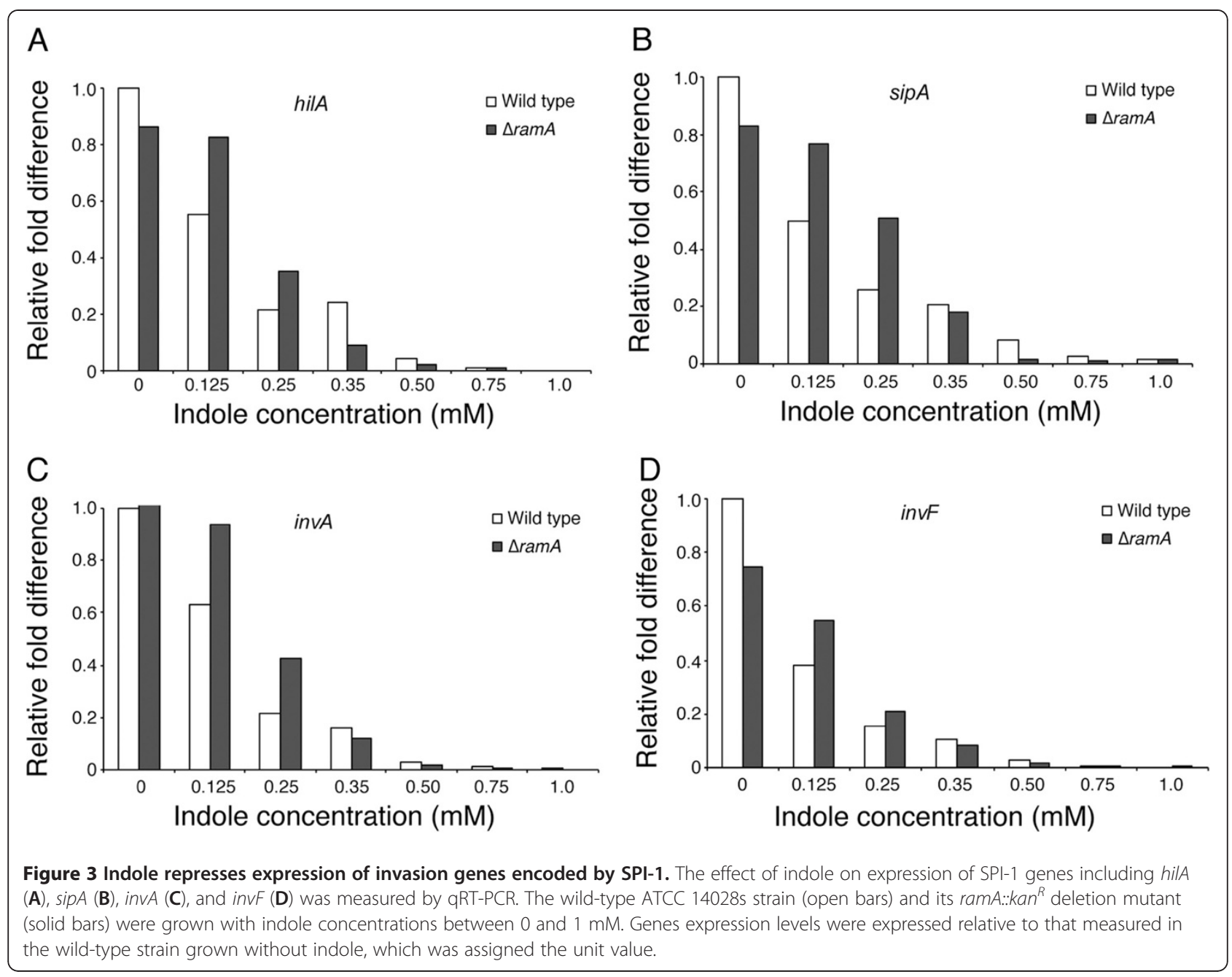

expression of SPI-1 genes, including the type III secretion system (T3SS). invF also encodes an invasion regulatory protein of SPI-1. sipA encodes an effector protein, the secretion of which is mediated by T3SS. invA encodes a structural component of T3SS. qRT-PCR revealed that indole decreased expression of hilA, $\operatorname{sip} A, \operatorname{inv} A$, and $i n v F$ in a concentration-dependent manner (Figure 3 ). Since it was reported that overexpression of $\operatorname{ram} A$ results in decreased expression of SPI-1 genes [47] and our study indicated that indole induces $\operatorname{ram} A$, we investigated the effect of $\operatorname{ramA}$ deletion on expression of SPI-1 genes regulated by indole. As shown in Figure 3 , indole repressed expression of hilA, $\operatorname{sip} A, \operatorname{inv} A$, and $i n v F$; however, its repressive effect on those in the $\operatorname{ram} A$-deleted mutant (14028s $\Delta r a m A:: \operatorname{kan}^{\mathrm{R}}$ ) was slightly lower than that observed in the wild-type strain (ATCC 14028s) when bacterial cells were treated with 0.125 or $0.25 \mathrm{mM}$ indole. In contrast, when bacterial cells were treated with concentrations of indole of $0.35 \mathrm{mM}$ or more, the repressive effect on SPI-1 genes was similar in the wild-type and in the mutant strains. These data suggest that indole partially represses SPI-1 genes in a RamA-dependent manner when cells are treated with lower indole concentrations; however, the repressive effect of indole on SPI-1 may be RamA-independent at higher concentrations.

A critical step in Salmonella pathogenesis is invasion of enterocytes and $M$ cells of the small intestine via expression of a type III secretion system encoded by SPI-1 that secretes effector proteins into host cells, leading to engulfment of bacteria within large membrane ruffles. As indicated previously, indole represses expression of genes encoded by SPI-1, suggesting that indole reduces invasion of mammalian cells by Salmonella. To examine this possibility, we investigated the effect of indole in an invasion assay using Caco-2 cells. When bacterial cells were treated with $1 \mathrm{mM}$ indole, the invasion rate of Salmonella was reduced compared to that in untreated bacterial cells (Figure 4). We also examined the effect of deletions of ramR and of the whole ram locus on invasive activity of Salmonella treated with $1 \mathrm{mM}$ indole. Indole repressed 


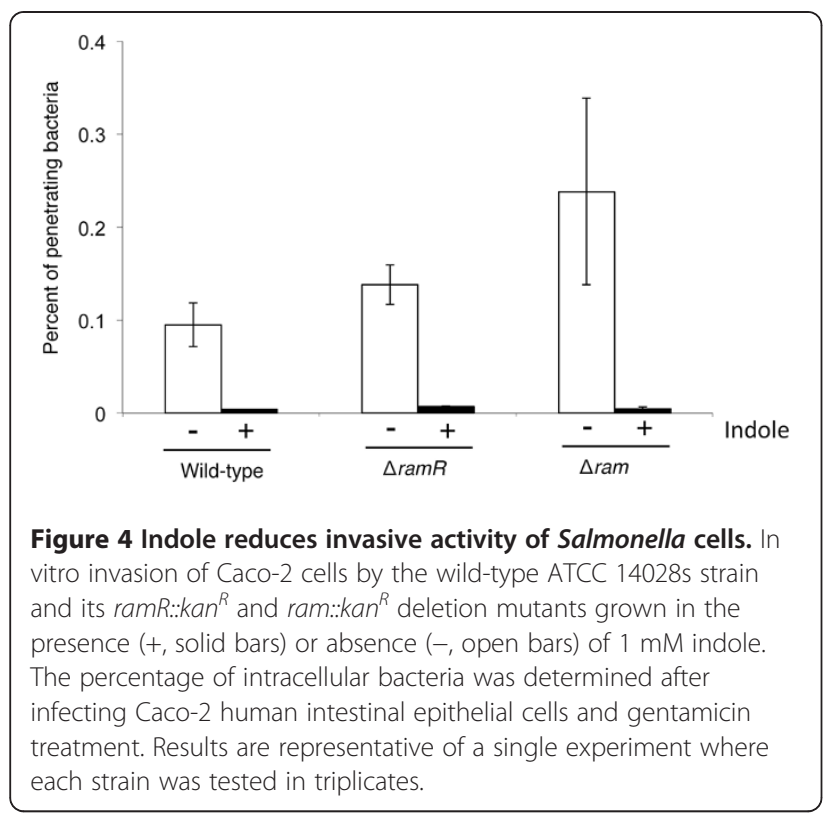

invasive activity of the $\Delta r a m R\left(14028 \mathrm{~s} \Delta r a m R:: \operatorname{kan}^{\mathrm{R}}\right)$ and of the $\Delta \mathrm{ram}$ mutant $\left(14028 \mathrm{~s} \Delta \mathrm{ram}:: \mathrm{kan}^{\mathrm{R}}\right)$, as observed with the wild-type strain (Figure 4). These data suggest that $1 \mathrm{mM}$ indole phenotypically represses invasive activity of Salmonella in a ram locus-independent manner.

\section{Discussion}

Increasing evidence indicates that indole controls various phenotypes of $E$. coli including multidrug resistance and virulence as an extracellular signal [28,31-34,37-39]. In contrast to E. coli, the effect of indole on Salmonella had not been clearly elucidated, probably because Salmonella does not produce indole. Therefore, we sought to resolve the effect of indole on gene expression in the S. enterica serovar Typhimurium ATCC $14028 \mathrm{~s}$ strain by microarray analysis. As hypothesized and confirmed in previous studies [35,36], microarray analysis revealed that indole increased expression of $\operatorname{ram} A$, which is involved in regulation of the AcrAB-TolC multidrug efflux system.

Including $\operatorname{ramA}, 24$ genes were upregulated by indole. Among them, 18 were more strongly induced by $4 \mathrm{mM}$ indole than by $1 \mathrm{mM}$ indole. Conversely, 53 genes were downregulated by indole, 51 of which were more strongly repressed by $4 \mathrm{mM}$ indole than by $1 \mathrm{mM}$ indole. These data suggested that expression of most indoleregulated genes is indole concentration dependent. In fact, promoter activity of ramA increased as indole

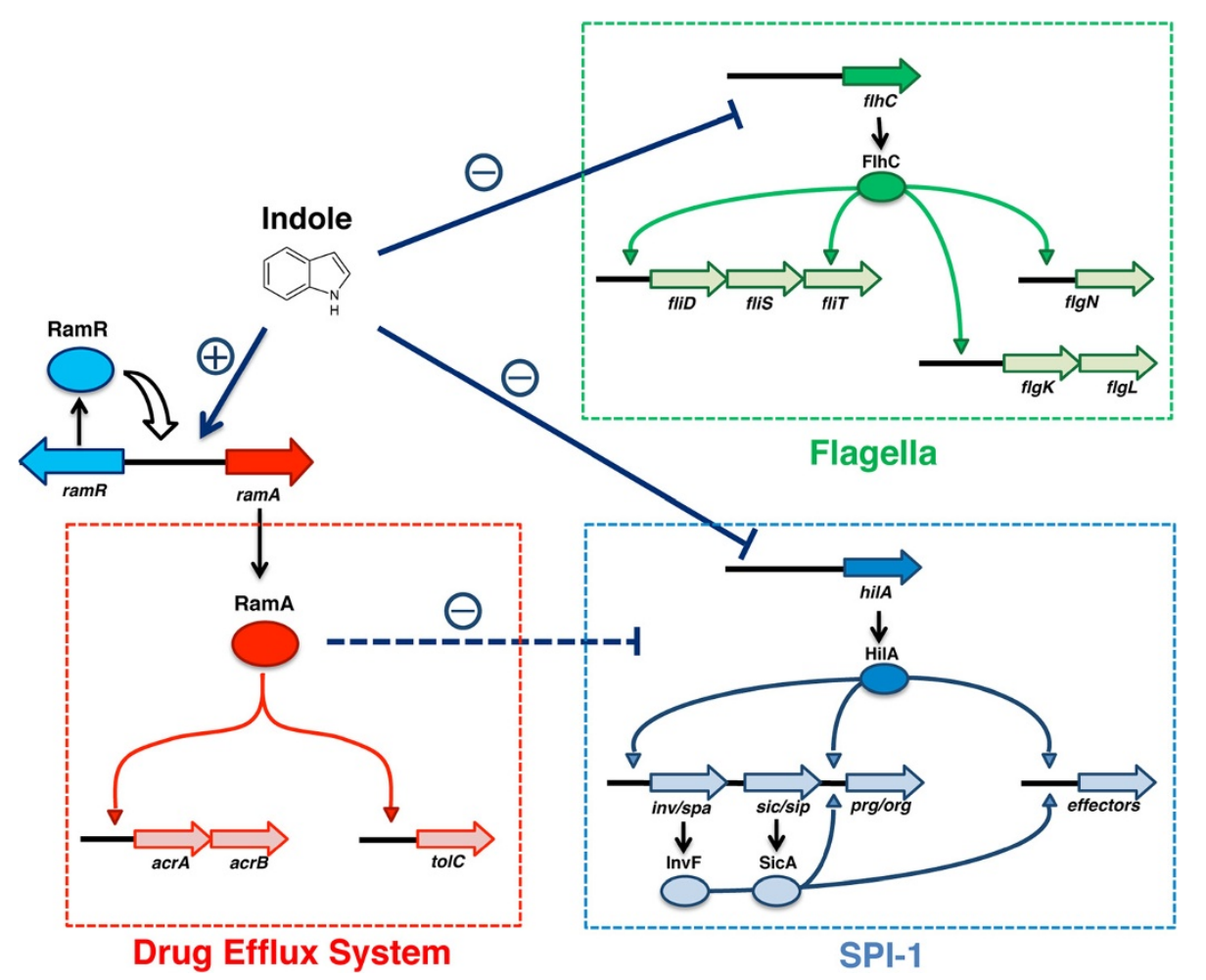

Figure 5 Proposed regulatory network controlled by indole. Indole induces the multidrug efflux system genes acr $A B$ and to/C through the increased expression of ramA. Indole represses flagellar and SPI-1 genes in a ram locus-independent manner. However, the indole-mediated upregulation of ramA may be partially involved in decreased expression of SPI-1 genes. 
concentration increased. Similarly, expression of SPI-1 genes decreased as indole concentration increased.

Indole induced $\operatorname{ram} A$, and this induction is probably responsible for induction of $a c r B$, which encodes the multidrug efflux pump (Figure 5). Most of the genes upregulated by indole encode putative proteins. Several of the genes, such as STM1251, STM1472, STM1868A, STM3941, and STM4213, have yet to be named. Among these, the only gene identified in E. coli is STM4213, which encodes a putative phage tail sheath protein. If the function of these putative genes is clarified, then other phenotypes induced by indole in addition to multidrug resistance will also be understood.

In this study, we found that indole repressed various genes related to bacterial motility and virulence. Decreased motility and invasive activity of Salmonella were also phenotypically observed. Recent studies revealed the coordinate regulation of flagellar and SPI-1 genes by FliZ, encoded by a gene in the fliA operon $[66,67]$. It was demonstrated that FliZ posttranslationally controls HilD to positively regulate expression of hilA [67]. Our microarray data revealed reduced expression of $f l i Z$ when bacterial cells were treated with indole ( $f l i Z$ expression was reduced to 0.47 - and 0.038 -fold of the level in untreated cells by 1 and $4 \mathrm{mM}$ indole, respectively), and that expression of hilA was also repressed by indole. Indole may coordinately repress flagellar and SPI-1 genes via the regulatory network of FliZ. Because previous study indicated that both RamA and RamR are involved in the control of SPI-1 genes [47], we examined their effects on repression of SPI-1 genes and invasive activity of Salmonella. The results suggested that indole suppresses SPI-1 genes in a RamA/RamR-independent manner (Figure 5). Similarly, repression of flh $C$ by indole was also RamA/RamR independent. These data are suggestive of the presence of another pathway for indole to repress flagellar and SPI-1 genes, whereas acrAB/tolC is induced by indole in a RamR/RamA-dependent manner. Bacterial adhesion to the Caco- 2 cells, which is the primary step of the cell invasion process, was not addressed in our experiments. However, since flagella were repressed by indole, it cannot be excluded that the defective invasion partially resulted from a lesser adhesion to the cells, and not only to the repression of SPI-1 genes. It should also be noted that several of the indole-repressed genes are related to anaerobic respiration in addition to motility and SPI-1 genes. Because it is suggested that indole is a biological oxidant in bacteria [68], this oxidative effect may lead to repression of these genes.

In conclusion, we identified that indole induces expression of genes related to efflux-mediated multidrug resistance and represses expression of genes related to invasive activity and motility of $S$. enterica serovar Typhimurium. Reduction of invasive activity and motility of Salmonella by indole was phenotypically observed. Because Salmonella itself does not produce indole, our results suggest that indole could also be an important signaling molecule for inter-species communication to control drug resistance and virulence of Salmonella in addition to its role in intra-species communication in $E$. coli. Indeed, it was previously demonstrated that $E$. coli-conditioned medium induced the AcrAB pump in Salmonella through the RamA regulator [35]. The type of environment in which Salmonella experiences the effect of indole is not well understood. It is believed that Salmonella may be exposed to high indole concentrations in the intestine, in which several species of indole-producing bacteria exist. In fact, indole is found in human feces at comparable concentrations $(\sim 250-1100 \mu \mathrm{M})[29,30]$, and recent studies indicated the importance of indole in favorable inter-kingdom signaling interactions between the intestinal epithelial cells and commensal bacteria [69]. In addition to indole itself, indole derivatives such as skatole (3-methylindole) also occur naturally in feces after being produced from tryptophan in the mammalian digestive tract. Therefore, indole and skatole may additively affect gene expression in Salmonella. In fact, when we examined the effect of skatole by a $\beta$-galactosidase assay, it significantly stimulated the promoter activity of $\operatorname{ram} A$ (unpublished data). Thus, there is a possibility that these molecules enhance drug resistance of Salmonella, while simultaneously repressing their motility and pathogenicity in the intestinal tract. Interestingly, the effect of indole on the pathogenicity of E. coli is the opposite of that on Salmonella. In enterohemorrhagic E. coli, it was suggested that indole can activate expression of EspA and EspB as well as secretion and stimulate the ability of EHEC to form attaching and effacing lesions in human cells [38]. Thus, although indole secreted by $E$. coli enhances the virulence of $E$. coli, it reduces the virulence of Salmonella, probably to the advantage of $E$. coli. This finding suggests that the gastrointestinal flora may affect regulation of virulence traits in Salmonella via the signaling of indole.

\section{Competing interests}

The authors declare that they have no competing interests.

\section{Acknowledgments}

We thank Mitsuko Hayashi-Nishino for the protocol for the invasion assay and excellent advice and Ikue Shirosaka, Coralie Porte-Lebiguais, Isabelle Monchaux and Imane Boumart for excellent technical assistance.

\section{Author details}

'Laboratory of Microbiology and Infectious Diseases, Institute of Scientific and Industrial Research, Osaka University, 8-1 Mihogaoka, Ibaraki, Osaka 567-00447, Japan. ${ }^{2}$ Department of Cell Membrane Biology, Institute of Scientific and Industrial Research, Osaka University, Ibaraki, Osaka, Japan. ${ }^{3}$ Graduate School of Pharmaceutical Sciences, Osaka University, Suita, Osaka, Japan. ${ }^{4}$ INRA, UMR1282 Infectiologie et Santé Publique, F-37380 Nouzilly, France. ${ }^{5}$ Université François Rabelais de Tours, UMR1282 Infectiologie et Santé Publique, F-37000 Tours, France. 


\section{Authors' contributions}

Conceived and designed the experiments: EN, EG, SB, AC, KN. Performed the experiments: EN, EG, SB, SY, AW. Analyzed the data: EN, EG, SB, SY, AW, KO, $\Pi$, AY, AC, KN. Wrote the paper: EG, AC, KN. All authors read and approved the final manuscript.

\section{Funding}

This research was supported in part by Grants-in-Aid from the Japan Society for the Promotion of Science and the Ministry of Education, Culture, Sports, Science and Technology of Japan; a grant from the Mishimakaiun Memorial Foundation; the Program for Promotion of Fundamental Studies in Health Sciences of the National Institute of Biomedical Innovation; and the Funding Program for Next Generation World-Leading Researchers. It was also partly supported by the French Région Centre (grant 2008 00036085) and partly by the European Union with the European Regional Development Fund (grant 1634-32245). The funders had no role in this study design, data collection and analysis, decision to publish, or preparation of the manuscript.

Received: 24 April 2012 Accepted: 25 May 2012

Published: 25 May 2012

\section{References}

1. Fuqua C, Winans SC, Greenberg EP: Census and consensus in bacterial ecosystems: the LuxR-Luxl family of quorum-sensing transcriptional regulators. Annu Rev Microbiol 1996, 50:727-751.

2. Fuqua WC, Winans SC, Greenberg EP: Quorum sensing in bacteria: the LuxR-Luxl family of cell density-responsive transcriptional regulators. J Bacteriol 1994, 176:269-275.

3. Kaiser D, Losick R: How and why bacteria talk to each other. Cell 1993, 73:873-885.

4. Kleerebezem M, Quadri LE, Kuipers OP, de Vos WM: Quorum sensing by peptide pheromones and two-component signal-transduction systems in Gram-positive bacteria. Mol Microbiol 1997, 24:895-904.

5. Salmond GP, Bycroft BW, Stewart GS, Williams P: The bacterial 'enigma': cracking the code of cell-cell communication. Mol Microbiol 1995, 16:615-624.

6. Cao JG, Meighen EA: Purification and structural identification of an autoinducer for the luminescence system of Vibrio harveyi. J Biol Chem 1989, 264:21670-21676.

7. Eberhard A, Burlingame AL, Eberhard C, Kenyon GL, Nealson KH, Oppenheimer NJ: Structural identification of autoinducer of Photobacterium fischeri luciferase. Biochemistry 1981, 20:2444-2449.

8. Holden MT, Ram Chhabra S, de Nys R, Stead P, Bainton NJ, Hill PJ, Manefield M, Kumar N, Labatte M, England D, et al: Quorum-sensing cross talk: isolation and chemical characterization of cyclic dipeptides from Pseudomonas aeruginosa and other gram-negative bacteria. Mol Microbiol 1999, 33:1254-1266.

9. Pearson JP, Gray KM, Passador L, Tucker KD, Eberhard A, Iglewski BH, Greenberg EP: Structure of the autoinducer required for expression of Pseudomonas aeruginosa virulence genes. Proc Natl Acad Sci USA 1994 91:197-201.

10. Pesci EC, Milbank JB, Pearson JP, McKnight S, Kende AS, Greenberg EP Iglewski BH: Quinolone signaling in the cell-to-cell communication system of Pseudomonas aeruginosa. Proc Natl Acad Sci USA 1999, 96:11229-11234.

11. Pesci EC: New signal molecules on the quorum-sensing block: response. Trends Microbiol 2000, 8:103-104.

12. Zhang L, Murphy PJ, Kerr A, Tate ME: Agrobacterium conjugation and gene regulation by N-acyl-L-homoserine lactones. Nature 1993, 362:446-448.

13. Baca-DeLancey RR, South MM, Ding X, Rather PN: Escherichia coli genes regulated by cell-to-cell signaling. Proc Natl Acad Sci USA 1999, 96:4610-4614

14. Bassler BL, Wright M, Showalter RE, Silverman MR: Intercellular signalling in Vibrio harveyi: sequence and function of genes regulating expression of luminescence. Mol Microbiol 1993, 9:773-786.

15. Cheng Q, Campbell EA, Naughton AM, Johnson S, Masure HR: The com locus controls genetic transformation in Streptococcus pneumoniae. Mol Microbiol 1997, 23:683-692.
16. Davies DG, Parsek MR, Pearson JP, Iglewski BH, Costerton JW, Greenberg EP: The involvement of cell-to-cell signals in the development of a bacterial biofilm. Science 1998, 280:295-298.

17. Engebrecht J, Nealson K, Silverman M: Bacterial bioluminescence: isolation and genetic analysis of functions from Vibrio fischeri. Cell 1983, 32:773-781.

18. Jones S, Yu B, Bainton NJ, Birdsall M, Bycroft BW, Chhabra SR, Cox AJ, Golby $P$, Reeves PJ, Stephens $S$, et al: The lux autoinducer regulates the production of exoenzyme virulence determinants in Erwinia carotovora and Pseudomonas aeruginosa. EMBO J 1993, 12:2477-2482.

19. Latifi A, Winson MK, Foglino M, Bycroft BW, Stewart GS, Lazdunski A, Williams P: Multiple homologues of LuxR and Luxl control expression of virulence determinants and secondary metabolites through quorum sensing in Pseudomonas aeruginosa PAO1. Mol Microbiol 1995, 17:333-343.

20. Passador L, Cook JM, Gambello MJ, Rust L, Iglewski BH: Expression of Pseudomonas aeruginosa virulence genes requires cell-to-cell communication. Science 1993, 260:1127-1130.

21. Piper KR, Beck von Bodman S, Farrand SK: Conjugation factor of Agrobacterium tumefaciens regulates Ti plasmid transfer by autoinduction. Nature 1993, 362:448-450.

22. Pirhonen M, Flego D, Heikinheimo R, Palva ET: A small diffusible signal molecule is responsible for the global control of virulence and exoenzyme production in the plant pathogen Erwinia carotovora. EMBO $J$ 1993, 12:2467-2476.

23. Clarke MB, Sperandio V: Events at the host-microbial interface of the gastrointestinal tract III. Cell-to-cell signaling among microbial flora, host, and pathogens: there is a whole lot of talking going on. Am J Physiol Gastrointest Liver Physiol 2005, 288:1105-1109.

24. Collier-Hyams LS, Neish AS: Innate immune relationship between commensal flora and the mammalian intestinal epithelium. Cell Mol Life Sci 2005, 62:1339-1348.

25. Green BT, Lyte M, Chen C, Xie Y, Casey MA, Kulkarni-Narla A, Vulchanova L, Brown DR: Adrenergic modulation of Escherichia coli 0157:H7 adherence to the colonic mucosa. Am J Physiol Gastrointest Liver Physiol 2004, 287: G1238-1246.

26. Sonnenwirth AC: The enteric bacteria and bacteroides. In Microbiology. 3rd edition. Edited by Davis BD, Dulbecco R, Eisen HN, Ginsberg HS. Publishers, Inc, Philadelphia, Pa: Harper \& Row; 1980:645-672.

27. Yanofsky C, Horn V, Gollnick P: Physiological studies of tryptophan transport and tryptophanase operon induction in Escherichia coli. $J$ Bacteriol 1991, 173:6009-6017.

28. Domka J, Lee J, Wood TK: YliH (BssR) and YceP (BssS) regulate Escherichia coli K-12 biofilm formation by influencing cell signaling. Appl Environ Microbiol 2006, 72:2449-2459.

29. Karlin DA, Mastromarino AJ, Jones RD, Stroehlein JR, Lorentz O: Fecal skatole and indole and breath methane and hydrogen in patients with large bowel polyps or cancer. J Cancer Res Clin Oncol 1985, 109:135-141.

30. Zuccato E, Venturi M, Di Leo G, Colombo L, Bertolo C, Doldi SB, Mussini E: Role of bile acids and metabolic activity of colonic bacteria in increased risk of colon cancer after cholecystectomy. Dig Dis Sci 1993, 38:514-519.

31. Wang $D$, Ding $X$, Rather PN: Indole can act as an extracellular signal in Escherichia coli. J Bacteriol 2001, 183:4210-4216.

32. Chant EL, Summers DK: Indole signalling contributes to the stable maintenance of Escherichia coli multicopy plasmids. Mol Microbiol 2007, 63:35-43.

33. Hirakawa H, Hayashi-Nishino M, Yamaguchi A, Nishino K: Indole enhances acid resistance in Escherichia coli. Microb Pathog 2010, 49:90-94.

34. Hirakawa H, Inazumi Y, Masaki T, Hirata T, Yamaguchi A: Indole induces the expression of multidrug exporter genes in Escherichia coli. Mol Microbiol 2005, 55:1113-1126.

35. Nikaido E, Yamaguchi A, Nishino K: AcrAB multidrug efflux pump regulation in Salmonella enterica serovar Typhimurium by RamA in response to environmental signals. J Biol Chem 2008, 283:24245-24253.

36. Nikaido E, Shirosaka I, Yamaguchi A, Nishino K: Regulation of the AcrAB multidrug efflux pump in Salmonella enterica serovar Typhimurium in response to indole and paraquat. Microbiology 2011, 157:648-655.

37. Anyanful A, Dolan-Livengood JM, Lewis T, Sheth S, Dezalia MN, Sherman MA, Kalman LV, Benian GM, Kalman D: Paralysis and killing of Caenorhabditis elegans by enteropathogenic Escherichia coli requires the bacterial tryptophanase gene. Mol Microbiol 2005, 57:988-1007.

38. Hirakawa H, Kodama T, Takumi-Kobayashi A, Honda T, Yamaguchi A: Secreted indole serves as a signal for expression of type III secretion system translocators in enterohaemorrhagic Escherichia coli 0157:H7. Microbiology 2009, 155:541-550 
39. Lee HH, Molla MN, Cantor CR, Collins JJ: Bacterial charity work leads to population-wide resistance. Nature 2010, 467:82-85.

40. Scherer CAaM SI: Principles of Bacterial Pathogenesis. Academic Press, New York 2001, :266-333

41. McClelland M, Sanderson KE, Spieth J, Clifton SW, Latreille P, Courtney L, Porwollik S, Ali J, Dante M, Du F, et al: Complete genome sequence of Salmonella enterica serovar Typhimurium LT2. Nature 2001, 413:852-856.

42. Fields PI, Swanson RV, Haidaris CG, Heffron F: Mutants of Salmonella typhimurium that cannot survive within the macrophage are avirulent. Proc Natl Acad Sci USA 1986, 83:5189-5193.

43. Miller JH: Experiments in Molecular Genetics. Cold Spring Harbor Laboratory Press, Cold Spring Harbor, NY 1972, :352-355.

44. Datsenko KA, Wanner BL: One-step inactivation of chromosomal genes in Escherichia coli K-12 using PCR products. Proc Natl Acad Sci USA 2000, 97:6640-6645.

45. Rosselin M, Virlogeux-Payant I, Roy C, Bottreau E, Sizaret PY, Mijouin L, Germon P, Caron E, Velge P, Wiedemann A: Rck of Salmonella enterica, subspecies enterica serovar enteritidis, mediates zipper-like internalization. Cell Res 2010, 20:647-664.

46. Abouzeed YM, Baucheron S, Cloeckaert A: ramR mutations involved in efflux-mediated multidrug resistance in Salmonella enterica serovar Typhimurium. Antimicrob Agents Chemother 2008, 52:2428-2434.

47. Bailey AM, Ivens A, Kingsley R, Cottell JL, Wain J, Piddock LJ: RamA, a member of the AraC/XylS family, influences both virulence and efflux in Salmonella enterica serovar Typhimurium. J Bacteriol 2010, 192:1607-1616.

48. Chollet R, Chevalier J, Bollet C, Pages JM, Davin-Regli A: RamA is an alternate activator of the multidrug resistance cascade in Enterobacter aerogenes. Antimicrob Agents Chemother 2004, 48:2518-2523.

49. Keeney D, Ruzin A, Bradford PA: RamA, a transcriptional regulator, and $A c r A B$, an RND-type efflux pump, are associated with decreased susceptibility to tigecycline in Enterobacter cloacae. Microb Drug Resist 2007, 13:1-6.

50. Li XZ, Nikaido H: Efflux-mediated drug resistance in bacteria: an update. Drugs 2009, 69:1555-1623.

51. Ruzin A, Immermann FW, Bradford PA: Real-time PCR and statistical analyses of acr $A B$ and ram $A$ expression in clinical isolates of Klebsiella pneumoniae. Antimicrob Agents Chemother 2008, 52:3430-3432.

52. Zheng J, Cui S, Meng J: Effect of transcriptional activators RamA and SoxS on expression of multidrug efflux pumps $A c r A B$ and AcrEF in fluoroquinolone-resistant Salmonella Typhimurium. J Antimicrob Chemother 2009, 63:95-102.

53. Horiyama T, Nikaido E, Yamaguchi A, Nishino K: Roles of Salmonella multidrug efflux pumps in tigecycline resistance. J Antimicrob Chemother 2011, 66:105-110.

54. Yamamoto K, Hirao K, Oshima T, Aiba H, Utsumi R, Ishihama A: Functional characterization in vitro of all two-component signal transduction systems from Escherichia coli. J Biol Chem 2005, 280:1448-1456.

55. Venkatesh GR, Kembou Koungni FC, Paukner A, Stratmann T, Blissenbach B, Schnetz K: BglJ-RcsB heterodimers relieve repression of the Escherichia coli bgl operon by H-NS. J Bacteriol 2010, 192:6456-6464.

56. Giel M, Desnoyer $\mathrm{M}$, Lopilato J: A mutation in a new gene, bglJ, activates the bgl operon in Escherichia coli K-12. Genetics 1996, 143:627-635.

57. Lambalot RH, Gehring AM, Flugel RS, Zuber P, LaCelle M, Marahiel MA, Reid R, Khosla C, Walsh CT: A new enzyme superfamily - the phosphopantetheinyl transferases. Chem Biol 1996, 3:923-936.

58. Gehring AM, Mori I, Walsh $C T$ : Reconstitution and characterization of the Escherichia coli enterobactin synthetase from EntB, EntE, and EntF. Biochemistry 1998, 37:2648-2659.

59. Feldheim DA, Chin AM, Nierva CT, Feucht BU, Cao YW, Xu YF, Sutrina SL, Saier MH Jr: Physiological consequences of the complete loss of phosphoryl-transfer proteins HPr and FPr of the phosphoenolpyruvate: sugar phosphotransferase system and analysis of fructose (fru) operon expression in Salmonella typhimurium. J Bacteriol 1990, 172:5459-5469.

60. Wang WF, Cheng X, Molineux IJ: Isolation and identification of fxsA, an Escherichia coli gene that can suppress $F$ exclusion of bacteriophage T7. J Mol Biol 1999, 292:485-499.

61. Rebbapragada A, Johnson MS, Harding GP, Zuccarelli AJ, Fletcher HM, Zhulin IB, Taylor BL: The Aer protein and the serine chemoreceptor Tsr independently sense intracellular energy levels and transduce oxygen, redox, and energy signals for Escherichia coli behavior. Proc Natl Acad Sci USA 1997, 94:10541-10546.
62. Brondijk TH, Fiegen D, Richardson DJ, Cole JA: Roles of NapF, NapG and $\mathrm{NapH}$, subunits of the Escherichia coli periplasmic nitrate reductase, in ubiquinol oxidation. Mol Microbiol 2002, 44:245-255.

63. Troxell B, Fink RC, Porwollik S, McClelland M, Hassan HM: The Fur regulon in anaerobically grown Salmonella enterica sv Typhimurium: identification of new Fur targets. BMC Microbiol 2011, 11:236.

64. Baucheron S, Coste F, Canepa S, Maurel MC, Giraud E, Culard F, Castaing B, Roussel A, Cloeckaert A: Binding of the RamR repressor to wild-Type and mutated promoters of the ramA gene involved in efflux-mediated multidrug resistance in Salmonella enterica serovar Typhimurium. Antimicrob Agents Chemother 2012, 56:942-948.

65. Claret $L$, Hughes $C$ : Functions of the subunits in the $F \mathrm{hD}_{2} \mathrm{C}_{2}$ transcriptional master regulator of bacterial flagellum biogenesis and swarming. J Mol Biol 2000, 303:467-478.

66. Saini S, Slauch JM, Aldridge PD, Rao CV: Role of cross talk in regulating the dynamic expression of the flagellar Salmonella pathogenicity island 1 and type 1 fimbrial genes. J Bacterio/ 2010, 192:5767-5777.

67. Chubiz JE, Golubeva YA, Lin D, Miller LD, Slauch JM: FliZ regulates expression of the Salmonella pathogenicity island 1 invasion locus by controlling HilD protein activity in Salmonella enterica serovar typhimurium. J Bacteriol 2010, 192:6261-6270.

68. Garbe TR, Kobayashi M, Yukawa H: Indole-inducible proteins in bacteria suggest membrane and oxidant toxicity. Arch Microbiol 2000, 173:78-82.

69. Bansal T, Alaniz RC, Wood TK, Jayaraman A: The bacterial signal indole increases epithelial-cell tight-junction resistance and attenuates indicators of inflammation. Proc Natl Acad Sci USA 2010, 107:228-233.

doi:10.1186/1757-4749-4-5

Cite this article as: Nikaido et al:: Effects of indole on drug resistance and virulence of Salmonella enterica serovar Typhimurium revealed by genome-wide analyses. Gut Pathogens 2012 4:5.

\section{Submit your next manuscript to BioMed Central and take full advantage of:}

- Convenient online submission

- Thorough peer review

- No space constraints or color figure charges

- Immediate publication on acceptance

- Inclusion in PubMed, CAS, Scopus and Google Scholar

- Research which is freely available for redistribution 